\title{
Analysis of the Process of Coal Micronization Conducted in Order to Obtain Coal-Water Liquids
}

\author{
A. Staroñ*, Z. KOWALski AND M. BANACH \\ Cracow University of Technology, Warszawska 24, 31-155 Cracow, Poland
}

\begin{abstract}
Coal is the most important energy source, but its application in traditional way causes pollution. Preparation of coal-water liquids consists of: initial crushing of coal, wet milling in mixer mill and homogenization. To obtain coal-water liquids there were used three kinds of materials: coal of medium assortment with a low content of ash (6-25 mm), fine coal $(0-20 \mathrm{~mm})$ and coal sludge. The parameters of the grinding process which results in coalwater suspensions characterized by the most advantageous functional properties (high stability, low density and viscosity and the smallest equivalent diameter of particles of coal in a slurry) have been chosen and the influence of additives on the listed properties of the suspensions was determined. For suspensions consisted of water and coal independent parameters were vibration frequency $301 / \mathrm{s}$, one ball with diameter of $15 \mathrm{~mm}$ and amount of water: $70 \mathrm{wt} \%$. Substances which were applied to improve the properties of coal-water suspensions were: Triton X-405, sodium carboxymethyl cellulose and poly(acrylic acid), partial sodium salt-graft-poly(ethylene oxide). The best stability, low viscosity and the lowest density of the suspensions were characterized by coal, water and $0.1 \mathrm{wt} \%$ of carboxymethyl cellulose as a result of the 30 min milling.
\end{abstract}

DOI: 10.12693 /APhysPolA.126.1025

PACS: $82.70 . \mathrm{Kj}$

\section{Introduction}

Coal is the primary energy source and one of the most important chemical raw materials. Using this material on a large-scale has a negative impact on the environment through the emission of gaseous pollutants $\left(\mathrm{SO}_{2}\right.$ $\mathrm{CO}_{2}$ and $\mathrm{NO}_{x}$ ) and the formation of solids by-products of combustion [1-4]. Taking into consideration the protection of the environment, the reduction of the consumption of conventional fuels should be applied. Technology of the production of coal-water slurry combined with rational management of energy may allow a permanent and sustainable system of economic development.

The basic components of coal-water fuel (suspension or a mixture of carbon) are fine-ground coal, water and various additives (stabilizers, viscosity reducing agents and antifoaming agents). Dispersion medium other than water could also be oil or methanol. The calorific value, the size distribution, stability, viscosity and solids contents are the parameters that characterize coal-water suspensions and determine the possibility of their application.

The calorific value characterizes coal-water fuel in terms of energy (for suspension of 49-75 wt\% of coal), it amounts $15.9-26.3 \mathrm{MJ} / \mathrm{kg}$ and depends on the amount of water and the type of coal of which the suspension was made [5].

Size distribution of coal in a slurry has a major impact on its rheological properties, and therefore it is a key element of all the reserved technology of suspension production $[6,7]$. The solids content is the parameter that

*corresponding author; e-mail: anilos@chemia.pk.edu.pl specifies the amount of coal in a slurry, it influences the viscosity and determines the calorific value of the fuel.

The viscosity of the coal-water slurry increases gradually together with the addition of carbon particles, until a critical point reaches, in which a large amount of particles causes their mutual friction and rapid increase in viscosity consequently the suspension stops flowing [8].

The stability of the suspension is dependent on the grain size composition and determines its quality and its application. Some dispersants such as surfactants and electrolytes are used to make coal-water suspensions more stable [9].

Surfactants cause moisturizing of the carbon particles and their separation by reducing the surface tension at the interface. This happens as a result of joining of the surfactant molecules to the carbon particles by adsorption or ionic interactions. Surfactants can be divided into ionized and non-ionized. In the first case, the ionic part of the substance is in direct contact with the carbon particle. The hydrophilic group is ionized in water, which leads to charging the carbon particles and the electrostatic repulsion and leads to the increase in dispersion [10-12].

Operation of non-ionic surfactants is to create a coating on the surface of the macromolecular carbon particles. This coating causes the steric repulsion affecting the dispersion of the particles in suspension positively.

Preparation of coal-water slurry consists of three steps: initial crushing of coal, which allows to apply the raw material to the mill; wet milling (that determines viscosity, density and the size distribution), and homogenization. Grinding wet coal can be carried out in roller mills, ball mills as well as in centrifugal, planetary and streaming mills $[13,14]$. 
The aim of the study was the selection of the parameters of the grinding process which results in coalwater suspensions characterized by the most advantageous functional properties such as: high stability, low density and viscosity and the smallest equivalent diameter of particles of coal in a slurry; and then examining the influence of additives on the listed properties of the suspensions obtained. On the basis of the result, the choice of the most preferred composition of water and carbon mixtures has been made.

\section{Experimental}

\subsection{Materials and methods}

The research was based on three coal raw materials bought from one coal factory, which differ in graining: coal of medium assortment with a low content of ash (6$25 \mathrm{~mm})$, fine coal $(0-20 \mathrm{~mm})$ and coal sludge. The content of water was $9.7,9.4$, and $7.5 \%$, respectively. Grains of coal of medium assortment and fine coal were characterized by sharp edges, different sizes, irregular shapes and a compacted structure. Particles of coal sludge were characterized by less variety in the size and were densely packed. Substances which were applied to improve the properties of coal-water suspensions were: Triton X-405 (a condensation product of ethylene oxide with a branched octylphenol, about 40 oxyethylene groups), sodium carboxymethyl cellulose and poly(acrylic acid), partial sodium salt-graft-poly(ethylene oxide), described in the literature $[9,15-17]$ as stabilizers used in the production of coal-water suspensions.

The humidity content was determined with the use of the WPS210S model of a RADWAG weightdryer, at a temperature of $105^{\circ} \mathrm{C}$, and the sampling time of $5 \mathrm{~s}$. Coal-water suspensions were obtained in mixer mill MM400 produced by Retsch, equipped with two stainless steel vessel with a capacity of $50 \mathrm{~cm}^{3}$ and a set of balls. The grinding jars of the MM 400 perform radial oscillations in a horizontal position. The inertia of the grinding balls causes them to impact with high energy on the sample material at the rounded ends of the grinding jars and to pulverize it. Moreover, the movement of the grinding jars combined with the movement of the balls resulted in the intensive mixing of the sample.

Independent variables characterizing coal-water suspensions were the content of individual components (10$30 \mathrm{wt} \%$ of coal, $70-90 \mathrm{wt} \%$ of water), number and diameter of balls $(\varphi)$ ( 1 ball with a diameter of $15 \mathrm{~mm}, 3$ balls $-12 \mathrm{~mm}$ or 6 balls $-10 \mathrm{~mm})$, the time $(t)(15,30$, or $60 \mathrm{~min})$ and the frequency of milling $(\tau)(15,22.5$, or $301 / \mathrm{s}$ ). Coal-water mixtures were prepared in a mixer mill for parameters presented in Table I. The additives in the amount of $0.1,0.8$, and $1.5 \mathrm{wt} \%$, relative to the weight of the suspension were used in ternary systems. The particle size in suspension was observed by scanning electron microscope Hitachi, model TM3000, with additional software NIS Elements Br 2.3 allowing to determine the
TABLE I

The parameters of preparation process of coal-water suspensions in mixer mill and the results of coal--water samples analysis.

\begin{tabular}{c|c|c|c|c|c|c|c|c|c}
\hline \hline Sample & Material & $\begin{array}{c}\tau \\
{[1 / \mathrm{s}]}\end{array}$ & $t[\mathrm{~s}]$ & $\begin{array}{c}\varphi \\
{[\mathrm{mm}]}\end{array}$ & $\begin{array}{c}\mathrm{H}_{2} \mathrm{O} \\
{[\mathrm{wt} \%]}\end{array}$ & $\begin{array}{c}H \\
{[\mathrm{~mm}]}\end{array}$ & $\begin{array}{c}\rho \\
{\left[\mathrm{g} / \mathrm{cm}^{3}\right]}\end{array}$ & $\begin{array}{c}\eta \\
{[\mathrm{mPas}]}\end{array}$ & $\begin{array}{c}d_{z} \\
{[\mu \mathrm{m}]}\end{array}$ \\
\hline 1 & coal & 30 & 30 & 15 & 90 & 48 & 1.03 & 0.9 & 8.5 \\
2 & coal & 15 & 60 & 15 & 90 & 50 & 1.03 & - & 10.1 \\
3 & sludge & 30 & 60 & 15 & 70 & 4 & 1.17 & 66.5 & 4.5 \\
4 & coal & 30 & 60 & 10 & 70 & 5 & 1.10 & 0.4 & 5.4 \\
5 & coal & 30 & 30 & 10 & 70 & 6 & 1.10 & 166.0 & 5.6 \\
6 & coal & 15 & 30 & 10 & 90 & 70 & 1.01 & 94.3 & 6.7 \\
7 & sludge & 15 & 30 & 15 & 70 & 8 & 1.17 & 35.3 & 4.4 \\
8 & sludge & 15 & 60 & 10 & 90 & 48 & 1.05 & 1.3 & 3.9 \\
9 & sludge & 30 & 30 & 15 & 90 & 20 & 1.05 & 0.4 & 3.5 \\
10 & coal & 15 & 60 & 15 & 70 & 14 & 1.10 & 14.4 & 8.5 \\
11 & sludge & 30 & 60 & 10 & 90 & 32 & 1.06 & 5.4 & 4.3 \\
12 & sludge & 15 & 30 & 10 & 70 & 12 & 1.17 & 35.9 & 6.0 \\
13 & sludge & 22.5 & 45 & 12 & 80 & 13 & 1.11 & 13.6 & 6.5 \\
14 & coal & 22.5 & 45 & 12 & 80 & 24 & 1.06 & 2.1 & 6.2 \\
15 & fine coal & 15 & 45 & 12 & 80 & 32 & 1.07 & 0.9 & 7.4 \\
16 & fine coal & 30 & 45 & 12 & 80 & 24 & 1.07 & 4.9 & 6.2 \\
17 & fine coal & 22.5 & 30 & 12 & 80 & 20 & 1.07 & 3.8 & 6.1 \\
18 & fine coal & 22.5 & 60 & 12 & 80 & 16 & 1.07 & 3.4 & 5.8 \\
19 & fine coal & 22.5 & 45 & 10 & 80 & 16 & 1.09 & 9.7 & 5.0 \\
20 & fine coal & 22.5 & 45 & 15 & 80 & 22 & 1.07 & 2.8 & 6.8 \\
21 & fine coal & 22.5 & 45 & 12 & 70 & 4 & 1.11 & 0.2 & 5.2 \\
22 & fine coal & 22.5 & 45 & 12 & 90 & 46 & 1.04 & - & 6.6 \\
23 & fine coal & 22.5 & 45 & 12 & 80 & 24 & 1.09 & 0.1 & 6.0 \\
24 & fine coal & 22.5 & 45 & 12 & 80 & 22 & 1.10 & 4.1 & 6.6 \\
& & & & & & & & \\
\hline
\end{tabular}

equivalent diameter $\left(d_{z}\right)$. The density $(\rho)$ of coal-water suspensions was assessed by pycnometric method and their viscosity $(\eta)$ using rheometer RHEOTEST Medingen $\mathrm{GmbH}$, RHEOTEST RN 3.1 for the shear rate of $100 / \mathrm{s}$ at the temperature of $25^{\circ} \mathrm{C}$. Stability $(H)$ of a mixture was defined as the difference $(\mathrm{mm})$ between the height of the surface of the mixture after its preparation, and a phase boundary formed by carbon particles that sedimented $24 \mathrm{~h}$ after homogenisation. Stability decreases with the increase of the height difference. The density, viscosity and the stability of coal-water slurry determine the possibility of its subsequent use as a fuel.

\section{Results}

Process parameters for the preparation of twocomponent mixtures and the results of the stability, density, viscosity and equivalent diameter of the particles are shown in Table I.

It is desirable for mixtures to have the greatest stability, the smallest density and viscosity, so that they could be stored and transported by pipelines. Samples no. 3, 4, 5 and 21 were characterized by the best stability. They are obtained from coal, fine coal and sludge with minimum time of grinding 30 min and minimum frequency of vibration of $22.51 / \mathrm{s}$. In these samples, the water content was $70 \mathrm{wt} \%$. The density of all obtained samples was in 
the range of $1.0-1.2 \mathrm{~g} / \mathrm{cm}^{3}$. Suspensions no. $1,2,22$ consisting of $90 \mathrm{wt} \%$ water (which diluted the mixtures) had the smallest density $\left(1.0 \mathrm{~g} / \mathrm{cm}^{3}\right)$.

The viscosities of the obtained samples were characterized by a wide range of the values from $0.1 \mathrm{mPas}$ for sample no. 23 to $166.0 \mathrm{mPas}$ for sample no. 5. Samples of no. 2 and 22 could not be determined because of their consistency that prevented the execution of the analysis. Total surface area of the carbon per unit of fuel is increased with decreased particle size of the carbon in the slurry (which increased the viscosity). Equivalent diameters determined for the particles of suspension were in the range of 3.5 (sample 9) to about $10 \mu \mathrm{m}$ (sample 2).

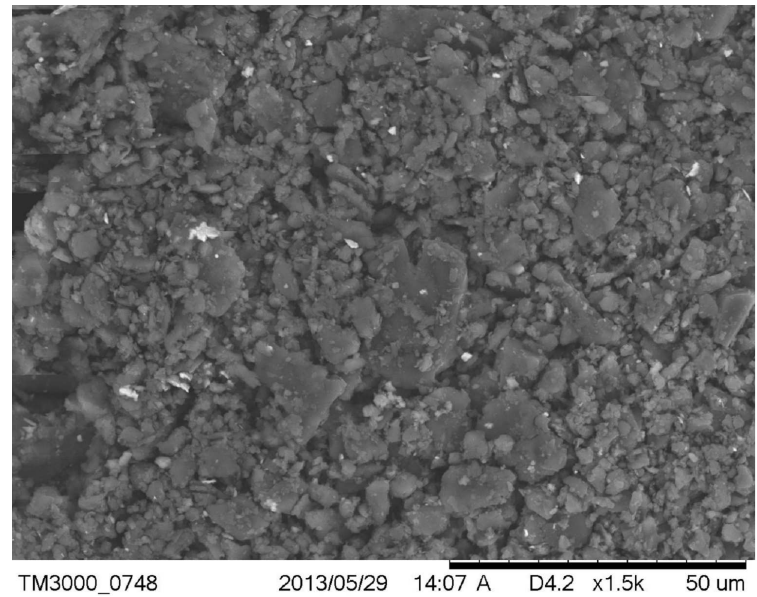

Fig. 1. Coal particles in slurry $(1500 \times)$.

Coal particles in the suspension, which were characterized by high stability (sample 4) are shown in Fig. 1. It is a suspension prepared by the milling process of coal after $30 \mathrm{~min}$ at a frequency of $30 \mathrm{1} / \mathrm{s}$, and balls having a diameter of $10 \mathrm{~mm}$. The stability of this slurry may be due to wide particle size distribution of coal in it, resulting in a higher packing density (fine coal particles fit into the spaces between the coarser grains).

Based on the survey and the analysis of the results obtained independent parameters were selected:

- vibration frequency $301 / \mathrm{s}$ to guarantee maximum stability

- one ball with diameter of $15 \mathrm{~mm}$. Maximum grinding aid should enable shredding large and hard pieces of material

- amount of water: $70 \mathrm{wt} \%$.

Coal-water-additive suspensions were obtained with these parameters. Process parameters and the results of the viscosity, density, stability, and the equivalent diameter of the coal particles in the resultant suspensions are shown in Tables II-IV.

The data collected in Tables II-IV show that none of the additives significantly affected the equivalent diam-
TABLE II

Parameters of process and the results of the analysis for coal-water-Triton X-405 suspensions.

\begin{tabular}{c|c|c|c|c|c|c|c}
\hline \hline Sample & Material & $\begin{array}{c}t \\
{[\mathrm{~min}]}\end{array}$ & $\begin{array}{c}\text { wt\% of } \\
\text { addition }\end{array}$ & $\begin{array}{c}d_{z} \\
{[\mu \mathrm{m}]}\end{array}$ & $\begin{array}{c}H \\
{[\mathrm{~mm}]}\end{array}$ & $\begin{array}{c}\rho \\
{\left[\mathrm{g} / \mathrm{cm}^{3}\right]}\end{array}$ & $\begin{array}{c}\eta \\
{[\mathrm{mPas}]}\end{array}$ \\
\hline 1 & sludge & 15 & 0.8 & 5.3 & 5 & 1.17 & 43.9 \\
2 & coal & 15 & 0.8 & 104.7 & & & \\
3 & sludge & 60 & 0.8 & 4.6 & 5 & 1.17 & 79.2 \\
4 & coal & 60 & 0.8 & 6.4 & 12 & 1.10 & 15.9 \\
5 & sludge & 30 & 0.1 & 5.0 & 6 & 1.17 & 65.4 \\
6 & coal & 30 & 0.1 & 6.3 & 9 & 1.10 & 24.5 \\
7 & sludge & 30 & 1.5 & 5.4 & 6 & 1.17 & 57.1 \\
8 & coal & 30 & 1.5 & 7.9 & & & \\
9 & fine coal & 15 & 0.1 & 6.6 & 11 & 1.11 & 21.3 \\
10 & fine coal & 60 & 0.1 & 7.1 & 7 & 1.11 & 36.7 \\
11 & fine coal & 15 & 1.5 & 7.0 & & & \\
12 & fine coal & 60 & 1.5 & 6.8 & 8 & 1.10 & 29.4 \\
13 & fine coal & 30 & 0.8 & 7.3 & 16 & 1.10 & 17.3 \\
14 & fine coal & 30 & 0.8 & 7.7 & 15 & 1.10 & 20.1 \\
15 & fine coal & 30 & 0.8 & 7.4 & 14 & 1.11 & 17.4
\end{tabular}

TABLE III

Parameters of process and the results of the analysis for coal-water-carboxymethyl cellulose suspensions.

\begin{tabular}{c|c|c|c|c|c|c|c}
\hline \hline Sample & Material & $\begin{array}{c}t \\
{[\mathrm{~min}]}\end{array}$ & $\begin{array}{c}\text { wt\% of } \\
\text { addition }\end{array}$ & $\begin{array}{c}d_{z} \\
{[\mu \mathrm{m}]}\end{array}$ & $\begin{array}{c}H \\
{[\mathrm{~mm}]}\end{array}$ & $\begin{array}{c}\rho \\
{\left[\mathrm{g} / \mathrm{cm}^{3}\right]}\end{array}$ & $\begin{array}{c}\eta \\
{[\mathrm{mPas}]}\end{array}$ \\
\hline 1 & sludge & 15 & 0.8 & 5.5 & 0.0 & 1.17 & 24.5 \\
2 & coal & 15 & 0.8 & 8.2 & 0.0 & 1.10 & 165.0 \\
3 & sludge & 60 & 0.8 & 5.3 & 0.0 & 1.18 & 97.7 \\
4 & coal & 60 & 0.8 & 5.5 & 0.0 & 1.10 & 187.0 \\
5 & sludge & 30 & 0.1 & 4.1 & 4.0 & 1.17 & 24.6 \\
6 & coal & 30 & 0.1 & 6.8 & 0.0 & 1.10 & 8.7 \\
7 & sludge & 30 & 1.5 & 10.1 & 0.0 & 1.17 & 66.8 \\
8 & coal & 30 & 1.5 & 6.3 & 0.0 & 1.11 & 82.7 \\
9 & fine coal & 15 & 0.1 & 8.8 & 0.0 & 1.11 & 6.2 \\
10 & fine coal & 60 & 0.1 & 8.7 & 3.0 & 1.11 & 6.8 \\
11 & fine coal & 15 & 1.5 & 7.5 & 0.0 & 1.11 & 62.1 \\
12 & fine coal & 60 & 1.5 & 7.4 & 0.0 & 1.11 & 81.7 \\
13 & fine coal & 30 & 0.8 & 5.4 & 0.0 & 1.10 & 26.5 \\
14 & fine coal & 30 & 0.8 & 6.1 & 0.0 & 1.11 & 30.7 \\
15 & fine coal & 30 & 0.8 & 10.3 & 0.0 & 1.10 & 33.6
\end{tabular}

eter of the coal particles in the suspension and its density. The density of the suspensions obtained were in the range of $1.1-1.2 \mathrm{~g} / \mathrm{cm}^{3}$, the equivalent diameter was amounted to $10 \mu \mathrm{m}$. The smaller the grain, the greater the share of the total surface area of the coal per unit of suspensions, may have caused its higher density. The slurry no. 2 obtained with the addition of Triton X-405 was an exception. It had coal particles having an equivalent diameter of more than $100 \mu \mathrm{m}$, which in turn influenced its stability, density and viscosity and made their assessment impossible. It can be assumed that the grinding time $(15 \mathrm{~min})$ in this case was too short. Moreover, 
TABLE IV

Parameters of process and the results of the analysis for coal-water-poly(acrylic acid), partial sodium salt-graftpoly (ethylene oxide) suspensions.

\begin{tabular}{c|c|c|c|c|c|c|c}
\hline \hline Sample & Material & $\begin{array}{c}t \\
{[\mathrm{~min}]}\end{array}$ & $\begin{array}{c}\text { wt\% of } \\
\text { addition }\end{array}$ & $\begin{array}{c}d_{z} \\
{[\mu \mathrm{m}]}\end{array}$ & $\begin{array}{c}H \\
{[\mathrm{~mm}]}\end{array}$ & $\begin{array}{c}\rho \\
{\left[\mathrm{g} / \mathrm{cm}^{3}\right]}\end{array}$ & $\begin{array}{c}\eta \\
{[\mathrm{mPas}]}\end{array}$ \\
\hline 1 & sludge & 15 & 0.8 & 5.2 & 3.0 & 1.17 & 9.5 \\
2 & coal & 15 & 0.8 & 7.4 & & & 1560.0 \\
3 & sludge & 60 & 0.8 & 4.2 & 2.0 & 1.18 & 11.8 \\
4 & coal & 60 & 0.8 & 5.3 & 0.0 & 1.11 & 59.0 \\
5 & sludge & 30 & 0.1 & 4.4 & 5.0 & 1.17 & 64.6 \\
6 & coal & 30 & 0.1 & 5.3 & 6.0 & 1.11 & 8.7 \\
7 & sludge & 30 & 1.5 & 5.7 & & & \\
8 & coal & 30 & 1.5 & 9.5 & & & 3390.0 \\
9 & fine coal & 15 & 0.1 & 6.7 & 8.0 & 1.11 & 10.5 \\
10 & fine coal & 60 & 0.1 & 9.9 & 4.5 & 1.12 & 50.3 \\
11 & fine coal & 15 & 1.5 & 6.8 & & & 17500.0 \\
12 & fine coal & 60 & 1.5 & 5.9 & 0.0 & 1.12 & 728.0 \\
13 & fine coal & 30 & 0.8 & 6.8 & 1.0 & 1.12 & 274.0 \\
14 & fine coal & 30 & 0.8 & 6.3 & 2.0 & 1.12 & 351.0 \\
15 & fine coal & 30 & 0.8 & 6.9 & 0.0 & 1.12 & 327.0
\end{tabular}

Triton $\mathrm{X}-405$ is a substance which reduces the viscosity, which might have resulted in gliding of fine coal particles between the grinding aid and the wall of the vessel, which led to incomplete grinding of the sample. In case of the mixtures with the addition of carboxymethyl cellulose, their better stability was observed compared with the mixtures obtained with the other additives. Carboxymethyl cellulose is used as an emulsifier, swells in water and has properties of the weak anionic electrolyte. The addition of this substance caused longer holding of comminuted coal particles in the entire volume of suspension (exception: samples 5 and 10). Suspensions obtained with Triton $\mathrm{X}-405$ and carboxymethyl cellulose (except is a sample no. 4) characterized by viscosity under $100 \mathrm{mPas}$. Significant dispersion of viscosity values from about 10 to $17.500 \mathrm{mPas}$ was observed in the case of coal-water-poly(acrylic acid) partial sodium salt-graftpoly (ethylene oxide) slurries. The addition of $0.1 \mathrm{wt} \%$ poly (acrylic acid) partial sodium salt-graft-poly (ethylene oxide) improved the properties of the slurry above $0.8 \mathrm{wt} \%$ consistency of suspension and it became thick and rubbery. The sort of raw material had impact on the density of the mixture in the case of ternary suspensions. The use of coal sludge resulted in increased density of suspension compared to suspensions obtained from coal or fine coal. This is caused by the composition of the sludge which is the waste formed after flotation in the production of coal containing inter alia gangue and mud of the settlers.

\section{Conclusions}

Based on the results of this research, it can be concluded that in the case of binary suspensions (e.g. coalwater material) the most preferable parameters for use are: vibration frequency of $30 \mathrm{1} / \mathrm{s}$, grinding time $30 \mathrm{~min}$, and a ball with a diameter of $15 \mathrm{~mm}$. In the case of ternary suspensions, the best stability, low viscosity and the lowest density of the suspension were characterized by coal, water and $0.1 \mathrm{wt} \%$ of carboxymethyl cellulose as a result of the 30 min milling.

\section{References}

[1] J. Kucowski, D. Laudyn, M. Przekwas, Energetyka a ochrona środowiska, WNT, Warszawa 1997 (in Polish).

[2] T. Doniecki, Analiza porównawcza mułów węglowych $z$ różnych rejonów wydobywczych jako materiałdo budowy barier izolacyjnych. Zrównoważona produkcja $i$ konsumpcja surowców mineralnych, Wydawnictwo IGSMiE PAN, Kraków 2011 (in Polish).

[3] J. Biegańska, M. Czop, Analiza odpadów górniczych $w$ aspekcie ich zagospodarowania. Zrównoważona produkcja $i$ konsumpcja surowców mineralnych, Wydawnictwo IGSMiE PAN, Kraków 2011 (in Polish).

[4] J. Dublewski, B. Madej, New developments in the polish mining industry - waste management rules now and in the future. Sustainable Post-Mining Land Management, CUPRUM OBR, Wrocław 2004.

[5] J. Hycnar, Wiadomości Górnicze 2, 63 (2001) (in Polish).

[6] Patent WO 81/01152.

[7] Patent US 4282006.

[8] R. Turian, J. Attal, D. Dung, L. Wedgewood, Fuel 81, 2019 (2002).

[9] Z. Aktas, E.T. Woodburn, Fuel Process. Technol. 62, 1 (2000).

[10] S. Lee, J.G. Speight, S.K. Loyalka, Handbook of Alternative Fuel Technologies, CRC Press Taylor \& Francis Group, New York 2007.

[11] J.S. Laskowski, Fizykochemiczne Problemy Metalurgii 24, 11 (1991) (in Polish).

[12] A. Al-Amrousi, M. Al-Sabagh, M. Osman, Fuel 75, 1193 (1996).

[13] Patent US 4265407.

[14] A. Heim, Procesy mechaniczne i urzadzenia do ich realizacji, Wydawnictwo Politechniki Łódzkiej, Łódź 1996 (in Polish).

[15] V. Seshadri, S.N. Singh, K.K. Jain, A.K. Verma, Mech. Eng. 89, 3 (2008).

[16] H.K. Naik, M.K. Mishra, U.M. Rao Karanam, Coal Combust. Gasif. Prod. 1, 25 (2009).

[17] E.S. Mosa, A.M. Saleh, T.A. Taha, A.M. El-Molla, Physicochem. Probl. Min. Process. 42, 107 (2008). 